\title{
Susceptibility of channel catfish fry to Channel Catfish Virus (CCV) challenge increases with age
}

\author{
Larry A. Hanson*, Mary R. Rudis, Lora Petrie-Hanson \\ Department of Basic Sciences, College of Veterinary Medicine, PO Box 6100, Mississippi State University, \\ Mississippi 39762, USA
}

\begin{abstract}
Susceptibility of channel catfish to Channel Catfish Virus Disease (CCVD) has been generally considered to be inversely related to age. However, in experimental immersion challenges, we found that channel catfish fry, 3 to $8 \mathrm{~d}$ post hatch (dph), are most resistant to CCV and susceptibility increases with age. Initial studies involved 2 spawns that had high CCV carrier percentage. To determine if the resistance seen in the fry was related to the CCV carrier status of the parents, we selected 4 spawns from CCV negative parents and 2 spawns from CCV positive parents and immersion challenged them at $8,23,36$ and 60 dph with $0,2.5 \times 10^{4}$ or $2.5 \times 10^{6}$ plaque forming units (PFU) of $\mathrm{CCV}^{-1}$. Survivors of the low-dose exposed groups were rechallenged at $120 \mathrm{dph}$ with $2.5 \times 10^{6}$ PFU CCV ${ }^{-1}$. Each brood demonstrated increasing susceptibility to CCVD with age and only the fish that were initially exposed at $60 \mathrm{dph}$ developed protective immunity. Time course assays evaluating tissue levels of virus in channel catfish exposed to CCV at 7, 21 and 42 dph suggested that the resistance was an early event in the infection process. The resistance in fry was most pronounced in fish from CCV positive spawns and was correlated to neutralizing antibody titers in the maternal parent in the $8 \mathrm{dph}$ challenge. However, other factors may be involved because all groups displayed the initial resistance and subsequent susceptibility to CCVD. The age effect may be an important influence on the progression of CCVD outbreaks and indicates the need to consider age for experimental challenges. Additionally, we documented the level of vertical transmission of CCV. Fry from the 4 positive spawns had a CCV prevalence of 40 to $75 \%$.
\end{abstract}

KEY WORDS: Disease susceptibility - Ictalurus punctatus - Teleost - Ictalurid herpesvirus · Herpesvirus latency $\cdot$ Herpesvirus vertical transmission $\cdot$ Maternal antibody

Resale or republication not permitted without written consent of the publisher

\section{INTRODUCTION}

Channel Catfish Virus Disease (CCVD) is a hemorrhagic viremia that occurs in young channel catfish. The causative agent is channel catfish virus, ictalurid herpesvirus 1 (CCV). CCVD induces high mortality and a predisposition to bacterial diseases (Fijan et al. 1970, Plumb 1978). The severity of a CCV epizootic gets worse with environmental stress and crowding. Such conditions are common in commercial catfish hatcheries and fingerling ponds. Because CCVD outbreaks are almost exclusively in young fingerlings and fry, an inverse relationship between age and CCVD susceptibility has been generally accepted (Plumb 1999). However, it has been shown that adults are susceptible to the disease (Hedrick et al. 1987). After ini- tial productive replication, CCV becomes latent. After the host fish matures, the virus is vertically transmitted to its offspring (Wise et al. 1988). Research using DNA probes suggests that populations of channel catfish having no history of CCV epizootics may harbor the virus (Wise et al. 1985). This data implies that CCV is similar to other herpesviruses in establishing a mature host-pathogen relationship. The factors that control productive replication of this virus and disease development in carrier populations are not understood.

An attenuated thymidine kinase (TK) negative CCV recombinant $\left(\mathrm{CCVTK}^{-}\right)$has been constructed that induces protective immunity in channel catfish fingerlings (Zhang \& Hanson 1995). Additionally, a TK- CCV recombinant that expresses the E. coli lacZ gene 
(CCVlacZ) was constructed that induces a humoral immune response to the foreign gene product in immersion exposed channel catfish fingerlings (Zhang $\&$ Hanson 1996). Therefore, this virus has great potential for use as a vaccine vector. A critical factor that would impact the utility of live CCV vaccines is the degree to which the CCV carrier status of channel catfish influences their susceptibility to CCV challenge. Also, in initial studies to evaluate the effects of age on the ability of $\mathrm{CCVTK}^{-}$to induce protective immunity in fry and fingerling channel catfish, we noted inconsistencies in the susceptibility of the same stock of fish at different ages. It appeared that as the fish aged they became more sensitive to CCVD. Therefore, we performed a series of challenge trials over a $2 \mathrm{yr}$ period to determine the influence of age and CCV carrier status on CCV susceptibility.

\section{MATERIALS AND METHODS}

Fish, cells and virus. Channel catfish virus (Auburn clone A) was obtained from the American Type Culture Collection and propagated in the channel catfish ovary cell line (CCO) as previously described (Kancharla \& Hanson 1996). CCO cells were propagated at $30^{\circ} \mathrm{C}$ in Dulbecco's modified Eagle's medium (DMEM) without sodium bicarbonate, supplemented with $10 \%$ fetal bovine serum and $25 \mathrm{mM} \mathrm{N}$-2-hydroxyethyl-piperazine-N2-ethanesulfonic acid buffer ( $\mathrm{pH}$ 7.4). All channel catfish used in this research were of the Big Black strain. Brood fish were maintained and spawned in ponds on the Mississippi Agricultural and Forestry Experiment Station (Starkville, MS). Egg masses were brought to the hatchery in the College of Veterinary Medicine, Mississippi State University where they were treated with $0.25 \mathrm{ml} \mathrm{l}^{-1}$ formalin for $1 \mathrm{~h}$ and hatched in separate flow-through tanks supplied with dechlorinated municipal tap water and continuous aeration. Fish were maintained at $27 \pm 1^{\circ} \mathrm{C}$ and fed commercial trout feed ad-libitum 4 times daily after they reached swim-up stage.

Year 1 challenge. Two egg masses collected from open pond spawned brood fish were hatched separately in indoor troughs and 20 fry were sampled on the day of hatch for polymerase chain reaction (PCR) analysis of CCV carrier status. These 2 broods were used in CCV challenge trials in which 2 replicate tanks of 20 fish from each brood were exposed to $0,1 \times 10^{5}$, $1 \times 10^{6}$ or $1 \times 10^{7} \mathrm{PFU}$ (plaque forming units) of CCV in $400 \mathrm{ml}$ of water (this gives $2.5 \times 10^{5}, 2.5 \times 10^{6}$ and $2.5 \times$ $10^{7} \mathrm{PFU} \mathrm{l}^{-1}$, respectively) for $30 \mathrm{~min}$ at $3,18,33$ and $59 \mathrm{~d}$ post-hatch (dph). Challenged fish were maintained for $10 \mathrm{~d}$ in 201 polypropylene tanks at $30^{\circ} \mathrm{C}$ supplemented with biological box type filters. Dead fish were counted, removed and individually placed in $1.5 \mathrm{ml}$ microcentrifuge tubes with approximately $5 \times$ the fish volume of homogenization medium (DMEM supplemented with $400 \mathrm{IU} \mathrm{ml}^{-1}$ penicillin, $400 \mu \mathrm{g} \mathrm{ml}^{-1}$ of streptomycin and $0.75 \mu \mathrm{g} \mathrm{ml}^{-1}$ amphotericin B). The caudal portion of the fish was removed, stored at $-70^{\circ} \mathrm{C}$ and later cultured for CCV to confirm CCVD as the cause of death. CCV culture was done by thawing the samples, homogenizing them using micro-pestles, centrifuging the homogenate at $12000 \times g$ for $5 \mathrm{~min}$ and inoculating CCO cells in a 24 well plate with $30 \mu \mathrm{l}$ of the supernatant per well. Cultures were considered CCV positive if the characteristic cytopathic effect (CPE) appeared within $10 \mathrm{~d}$ when incubated at $30^{\circ} \mathrm{C}$.

Year 2 challenges. The eggs from 5 spawns from selectively paired-cage spawned brood fish and 1 open pond spawn were separately hatched and sampled for PCR analysis. The 6 spawns were selected because they were age matched. Of the selected spawns, 4 were from CCV negative parents and 1 was from CCV positive parents. The carrier status of the open pond spawn was unknown. Three replicate tanks of 30 fish from each brood were immersion challenged at $8,23,36$ and $60 \mathrm{dph}$ with $0,1 \times 10^{4}$ or $1 \times 10^{6} \mathrm{PFU}$ of $\mathrm{CCV}$ in $400 \mathrm{ml}$ of water (this gives $2.5 \times 10^{4}$ and $2.5 \times$ $10^{6} \mathrm{PFU} \mathrm{l}^{-1}$, respectively) for $30 \mathrm{~min}$ and placed in $40 \mathrm{l}$ flow-through tanks at $29^{\circ} \mathrm{C}$. The tanks were observed for $14 \mathrm{~d}$. Dead fish were counted and cultured to confirm CCVD as the cause of death as described above. Survivors of the low dose exposed groups were subsampled for serum neutralization assays at $120 \mathrm{dph}$ and the remainder were rechallenged with $1 \times 10^{6} \mathrm{PFU}$ of CCV in $400 \mathrm{ml}$ of water. The influence of age on cumulative mortality and influence of maternal antibody titers on cumulative mortality were determined using regression analysis and 1-way analysis of variance (ANOVA) using SSPS software. Comparison of cumulative mortality between fish from CCV-positive spawns and CCV-negative spawns were made using a 2 tailed $t$-test for independent samples.

Virus replication assays. Channel catfish from a CCV negative spawn were challenged as described above at 7,21 and $42 \mathrm{dph}$. The challenges were done using 2 groups of fish per age group. One received $3 \times$ $10^{4} \mathrm{PFU}$ and the other received $1 \times 10^{6} \mathrm{PFU}$ of CCV per $400 \mathrm{ml}$ of water. The fish were sampled at 1, 2, 3 and $5 \mathrm{~d}$ post infection for the high-dosage groups and 1, 2, $3,5,7$ and $11 \mathrm{~d}$ post challenge for the low-dosage group. Sampled fish were killed by an overdose of tricaine methane sulfonate, weighed and placed into a measured volume of homogenization medium that was approximately $5 \times$ the fish volume. The samples were stored at $-70^{\circ} \mathrm{C}$ until processed. Whole body virus loads were determined by titering the virus on $\mathrm{CCO}$ cells and calculating the $50 \%$ endpoint tissue culture 
infectious dose TCID50 $\mathrm{g}^{-1}$. This was done by homogenizing the whole fish using micro-pestles for the fish from the 7 and 21 dph challenges and an Omni 2000 homogenizer (Omni International) for fish from the 42 dph challenge. The sample was centrifuged at $12000 \times g$ for 5 min and the supernatant was dilution plated onto 96-well tissue culture plates. Serial 5-fold dilutions were done using serum free cell culture medium and 6 replicate wells recieved $100 \mu \mathrm{l}$ per well of each dilution for each sample. Each well was overlayed with $100 \mu \mathrm{l}$ of cell culture medium with $20 \%$ FCS containing $3 \times 10^{4} \mathrm{CCO}$ cells (suspended by trypsin digestion). Plates were incubated for $7 \mathrm{~d}$, fixed with formalin and stained with crystal violet. Wells with CPE were scored and the TCID50 was determined using the method of Kärber (1931).

PCR. Peripheral blood leukocytes were used for PCR assays on brood fish. The fish were restrained without anesthesia and bled from the caudal vein into $2 \mathrm{ml}$ Vacutainer tubes containing EDTA and placed on ice. Each fish was identified using a needleless injector-mediated Evan's blue tattoo on the abdomen for later identification and selective pairing for spawning. Leukocytes were isolated from the blood by overlaying $0.5 \mathrm{ml}$ onto $1 \mathrm{ml}$ of Histopaque 1088 (Sigma) in a $1.5 \mathrm{ml} \mathrm{mi-}$ crofuge tube. The samples were centrifuged at $500 \times g$ at room temperature for 20 min using the 'soft-spin' setting in an Eppendorf 5417 centrifuge. The opaque, diffuse band of leukocytes was harvested and suspended in $0.5 \mathrm{ml}$ of Hanks balanced salts solution (HBSS) and pelleted at $5000 \times g$ for $5 \mathrm{~min}$, and DNA was extracted from the pellet. The DNA for CCV-specific PCR on fry was extracted from the whole body after yolk sac removal. DNA was isolated from leukocytes and fry using the Puregene DNA isolation kit (Gentra Systems). The initial DNA purification step from the fry was an overnight digestion at $55^{\circ} \mathrm{C}$ with $60 \mu \mathrm{g}$ Proteinase $\mathrm{K}$ in $600 \mu \mathrm{l}$ lysis buffer as recommended by the manufacturer. PCR assays were performed using a modification of the method of Kancharla \& Hanson (1996). We used primers RO1 and RO3 (Boyle \& Blackwell 1991), and the $167 \mathrm{bp}$ internal standard with a heat-activated Taq polymerase (Taq Gold, Perkin Elmer) and a hot-start step. In this modification, the reaction was initially incubated at $95^{\circ} \mathrm{C}$ for $8 \mathrm{~min}$ to activate the polymerase. Results were evaluated by electrophoresis on $10 \%$ polyacrylamide gels with ethidium bromide staining and observation by UV transillumination.

Serum neutralization. Blood samples from fingerlings were collected from the caudal vein of sampled fish in microcapillary tubes and allowed to clot overnight at $4{ }^{\circ} \mathrm{C}$. Then, the samples were centrifuged in a microhematocrit centrifuge for $5 \mathrm{~min}$, the tubes were scored and broken just above the clot, and the serum was expelled into microcentrifuge tubes and stored at $-70^{\circ} \mathrm{C}$ until used. Before use, each sample was incubated at $45^{\circ} \mathrm{C}$ to inactivate complement. Serum neutralization assays were done by mixing a $15 \mu \mathrm{l}$ of virus stock diluted to contain $60 \mathrm{PFU}$ of CCV with an equal volume of 1:5, 1:20, 1:80 or 1:320 dilutions of sera in calcium- and magnesium-free Hanks' balanced salts solution, and incubated at $30^{\circ} \mathrm{C}$ for 60 min. Each serum-virus mixture was then combined with approximately $2 \times 10^{5}$ suspended, trypsinized $\mathrm{CCO}$ cells in $1 \mathrm{ml}$ of medium, inoculated into a well of a 24 well tissue culture plate and incubated at $30^{\circ} \mathrm{C}$ for $24 \mathrm{~h}$. A negative control (non-neutralizing serum from $\mathrm{CCV}$ negative channel catfish) and a positive control (positive serum from a channel catfish IP injected with CCV) antiserum was run on every other plate. The plates were fixed with $10 \%$ formalin, stained with crystal violet and plaques counted. Neutralization tests using plasma from brood fish were done using similar methods, except plasma was obtained from EDTAtreated blood samples taken for PCR analysis (see above). The assays were done using $30 \mu \mathrm{l}$ of plasma and $30 \mu \mathrm{l}$ of virus (with $60 \mathrm{PFU}$ of CCV) per well and triplicate wells were inoculated per virus dilution for each fish. The $50 \%$ reduction endpoint was found using an EXCEL spreadsheet (Microsoft Corporation) with the Kärber calculation (Kärber 1931).

\section{RESULTS}

\section{Year 1 trial}

The fish from 2 age-matched spawns were evaluated for CCV sensitivity. The 2 broods were CCV positive and had a prevalence of 64 and $50 \%$, respectively, as determined by PCR. The channel catfish from CCV positive spawns were initially very resistant to CCV and became more sensitive as they aged (Fig. 1a). The correlation with age was significant (Fig. 2a). The presence of latent $\mathrm{CCV}$ in the fry before challenge suggests that one or both parents were CCV positive and suggests that the mother may have had anti-CCV antibodies. Because this first trial used fish from open pond spawns, we were unable to evaluate the CCV specific antibody or the $\mathrm{CCV}$ carrier status of the parents. Therefore, a second trial was performed using fry from egg masses produced by cage spawning with known parents.

\section{Year 2 trial}

Fish from 5 broods obtained from selected pen spawning (Spawns 2, 16, 18, 19 and 22) and 1 from an open pond spawn (spawn K) were evaluated for sensitivity to CCVD. The spawns were chosen because they 

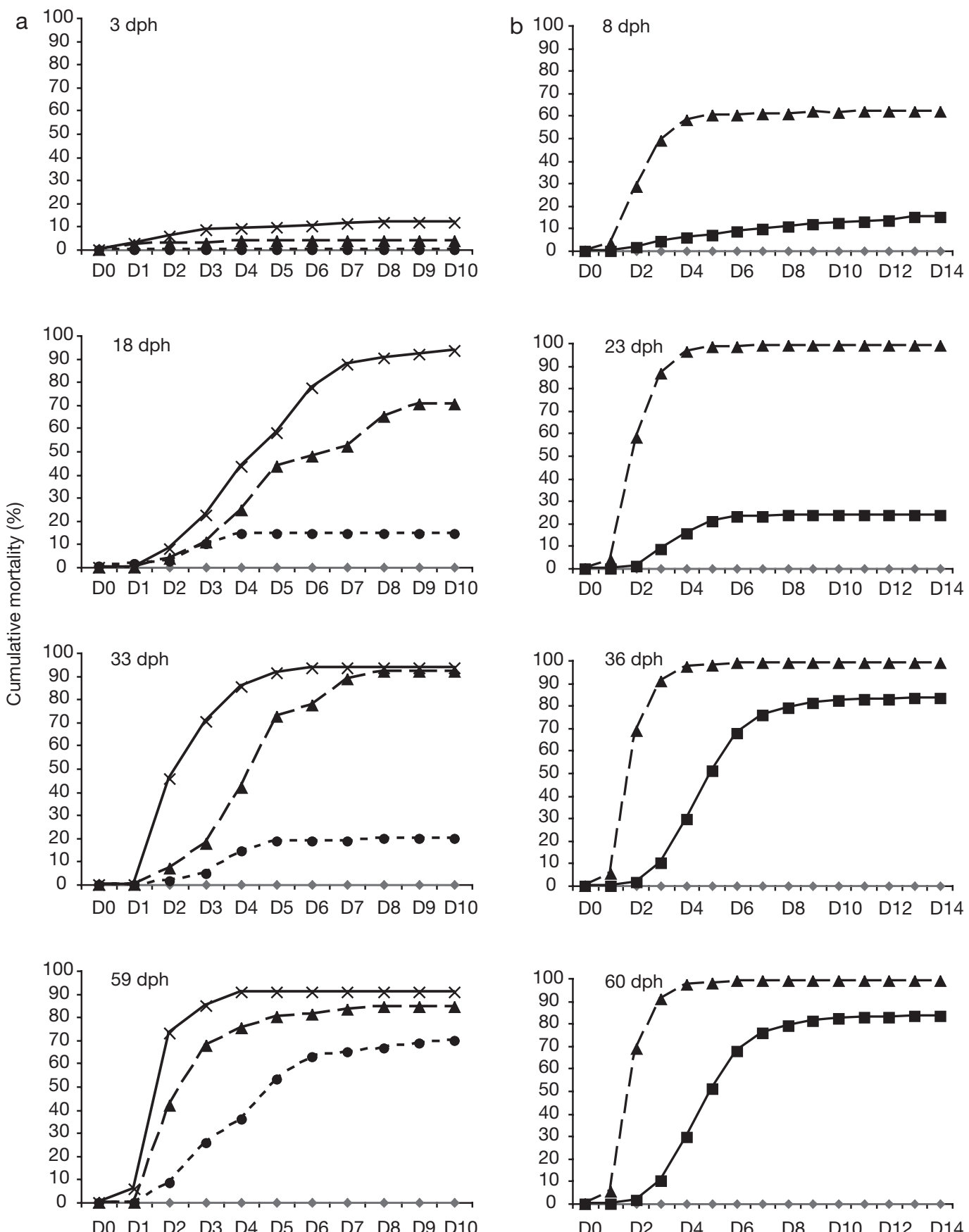

Fig. 1. Ictalurus punctatus. Mean cumulative mortality over time of channel catfish at various ages after exposure to CCV by im-

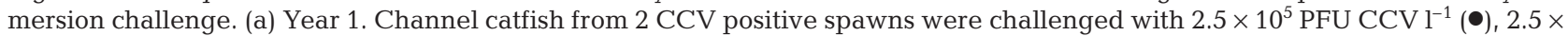
$10^{6} \mathrm{PFU} \mathrm{CCV}^{-1}(\mathbf{\Lambda}), 2.5 \times 10^{7} \mathrm{PFU} \mathrm{CCV}^{-1}(\times)$ and noninfected controls $(\diamond)$ at 3, 18, 33 and 59 dph (day post-hatch). (b) Year 2.

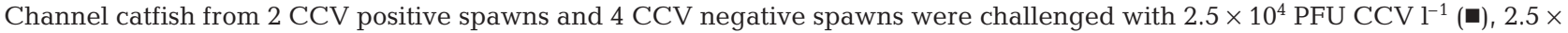
$10^{6} \mathrm{PFU} \mathrm{CCV}^{-1}(\mathbf{\Delta})$ and noninfected controls $(\diamond)$ at $8,23,36$ and $60 \mathrm{dph}$. PFU: plaque forming unit. D is day post-exposure

were age-matched, allowing simultaneous challenge evaluations. Two spawns designated $\mathrm{K}$ and 16 were CCV positive, with 75 and $40 \%$ of the fry being positive for latent CCV by PCR, respectively. Spawns 2, 18,
19 and 22 were CCV negative. The results were similar to those obtained for the Year 1 trial; young fish were most resistant to CCV and became more susceptible with age (Fig. 1b). 
The low-dose infections optimally demonstrated the trend in susceptibility because the high-dose challenges caused nearly $100 \%$ mortality in all groups except the $8 \mathrm{dph}$ group. However, both doses demonstrated a significant correlation of CCV susceptibility with age (Fig. 2b). The resistance was higher in the CCV positive fish in the 8 dph challenge $(\mathrm{p}<0.01)$ in the high-dose experiment and in the $23 \mathrm{dph}$ challenge in the low-dose experiment $(p<0.05)$ but was not significantly different between the groups in the other challenges. The percentage cumulative mortality in the high-dose experiment of the fish exposed at $8 \mathrm{dph}$ was $43.5 \pm 6.4$ (mean $\pm \mathrm{SE}$ ) in the CCV positive spawns and $72.2 \pm 5.1$ in the CCV negative fish. The percentage cumulative mortality in the low-dose experiment of the fish exposed at $23 \mathrm{dph}$ was 0 in the $\mathrm{CCV}$ positive spawns and $37.8 \pm 15.5$ in the CCV negative fish.
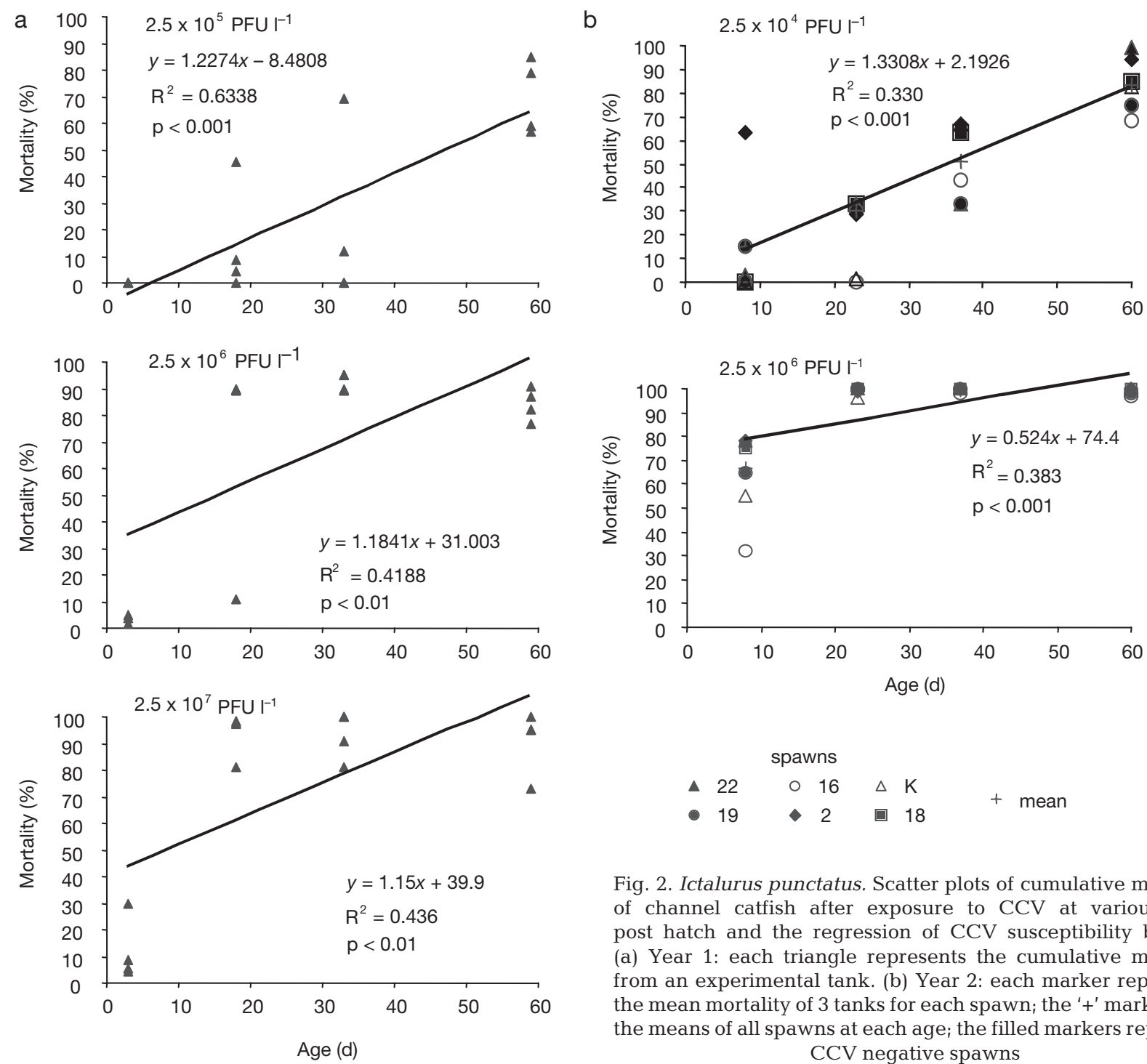

To determine if the fish given the virus at an early age had developed an acquired immune response to the virus, blood samples were drawn and survivors from the low-dose challenges were re-challenged with $2.5 \times 10^{6} \mathrm{PFU} \mathrm{l}^{-1}$ of CCV at $120 \mathrm{~d}$ post hatch. Neutralizing antibody titers were below the log 2 value generally used as the cut-off for positive neutralization, but the values were significantly greater than controls in the fish from the 8, 36 and 60 dph challenges (Fig. 3a). However, significant protection was only demonstrated in fish that were exposed to the virus at $60 \mathrm{dph}$ (Fig. 3b).

Plasma that was obtained from 5 of the 6 female parents during the pre-spawning bleed (blood was drawn for PCR to determine CCV carrier state before spawning), was evaluated for CCV neutralizing ability. The $\log$ titers for the female parents of Spawns 2, 16, 18, 19

Fig. 2. Ictalurus punctatus. Scatter plots of cumulative mortality of channel catfish after exposure to CCV at various ages post hatch and the regression of $\mathrm{CCV}$ susceptibility by age. (a) Year 1: each triangle represents the cumulative mortality from an experimental tank. (b) Year 2: each marker represents the mean mortality of 3 tanks for each spawn; the ' + ' markers are the means of all spawns at each age; the filled markers represent CCV negative spawns 

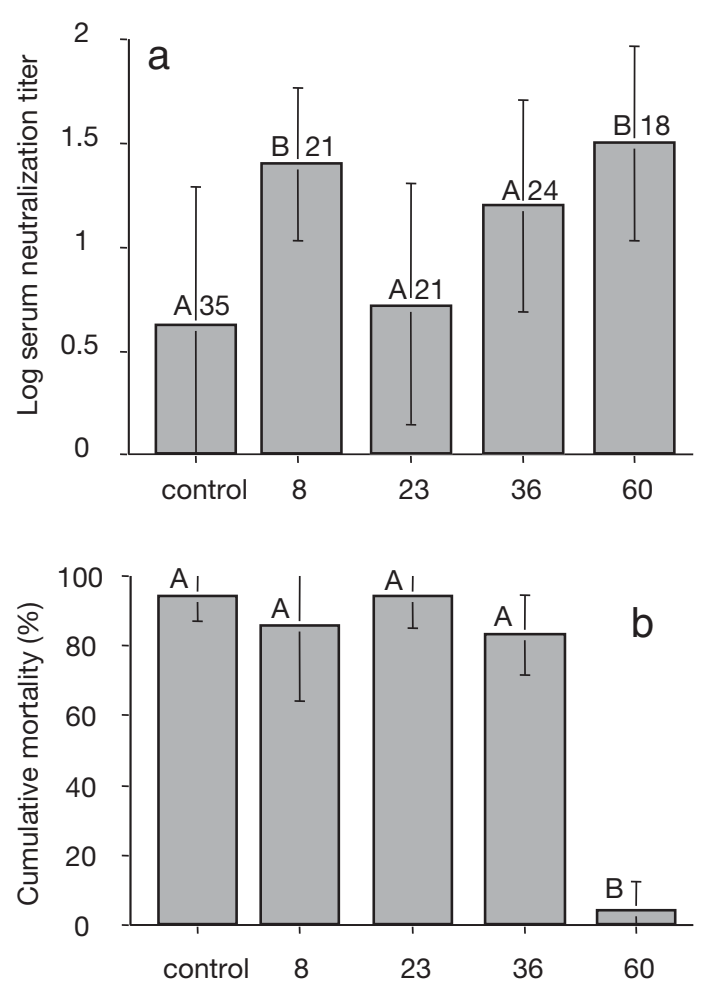

Age in days post hatch when exposed to CCV

Fig. 3. Ictalurus punctatus. Bar graphs of (a) neutralization titers before challenge and (b) cumulative mortality of fish from Year 2 after challenge with $2.5 \times 10^{6} \mathrm{PFU} \mathrm{CCV}^{-1}$ at $120 \mathrm{dph}$. Values are mean $\pm \mathrm{SD}$. Means that do not share a common letter designation are significantly different $(p<0.05)$. Numbers of fish used in serum neutralization assays are indicated above each bar

and 22 were $1.12,2.27,2.19,2.09$ and 1.99, respectively. It is noteworthy that the female parent of spawn 16 had the highest neutralizing titer and had a $40 \%$ sample prevalence of CCV in its offspring. Because Spawn K was an open pond spawn, no plasma was available from its maternal parent. Regression analysis demonstrated a significant inverse correlation of maternal antibody titer to the cumulative mortality of the respective spawns in the $8 \mathrm{dph}$ low-dose experiment (Fig. 4).

Because the different sensitivity of developing fry to CCV may represent differences in level of infection, differences in replication in the host or differences in pathogenesis, we evaluated the ability of CCV to infect and replicate in channel catfish fry at 7,21 and $42 \mathrm{dph}$. We did this by quantifying total infectious virus in the fish at various times after exposure to low dose or a high dose of virus.

In the low-dose challenges, only fish exposed at $42 \mathrm{dph}$ demonstrated detectable levels of virus. Of this

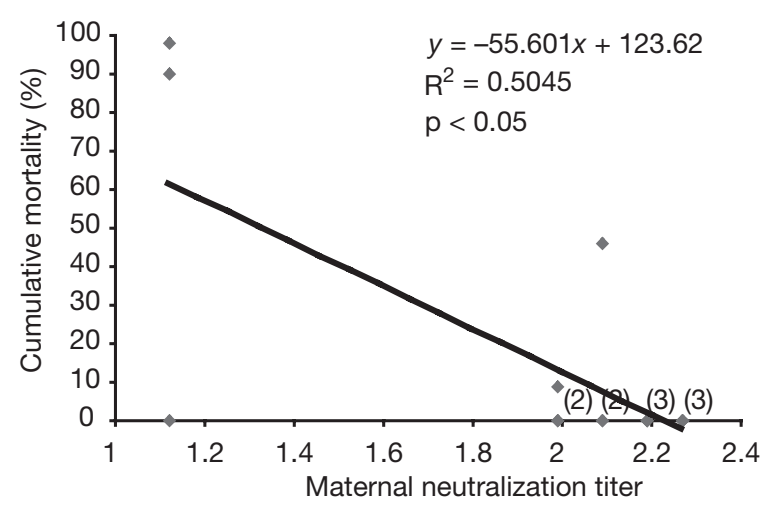

Fig. 4. Ictalurus punctatus. Scatter plot and regression demonstrating the relationship of percentage cumulative mortality in the 8 dph challenge with $2.5 \times 10^{4} \mathrm{PFU} \mathrm{CCV} \mathrm{l}^{-1}$ from each spawn to the neutralizing antibody titer of the maternal parent. Each marker represents an experimental tank. Numbers in parentheses indicate the number of tanks with the same value

group, no fish cultured positive on 1 and $2 \mathrm{~d}$ postexposure, $50 \%$ were positive on $3 \mathrm{~d}$ post-exposure and all were positive on Days 5, 7 and 11 post exposure (Table 1).

In the high-dose challenges, $10 \%$ of fish in all age groups were $\mathrm{CCV}$ positive at $1 \mathrm{~d}$ post-exposure. On the second day, $38 \%$ of fish exposed at $7 \mathrm{dph}, 75 \%$ of fish exposed at $21 \mathrm{dph}$ and $100 \%$ of fish exposed at $42 \mathrm{dph}$

Table 1. Ictalurus punctatus. Evaluation of virus loads at various times post infection of channel catfish infected at 7,21 and 42 dph (day post-hatch). BDL: below detectable limit

\begin{tabular}{|c|c|c|c|c|}
\hline 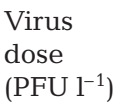 & $\begin{array}{l}\text { Fish } \\
\text { age } \\
\text { (dph) }\end{array}$ & $\begin{array}{l}\text { Day post- } \\
\text { infection }\end{array}$ & $\begin{array}{c}\% \\
\text { infected }\end{array}$ & $\begin{array}{c}\text { Highest virus } \\
\text { load TCID50 } \\
g^{-1}\left(10^{6}\right)\end{array}$ \\
\hline \multirow[t]{8}{*}{$7.5 \times 10^{4}$} & 7 & $1-11$ & 0 & BDL \\
\hline & 21 & $1-11$ & 0 & BDL \\
\hline & 42 & $1-2$ & 0 & BDL \\
\hline & 42 & 3 & 50 & 0.18 \\
\hline & 42 & 5 & 100 & 1.2 \\
\hline & 42 & 7 & 83 & 3.5 \\
\hline & 42 & 9 & 100 & 2.1 \\
\hline & 42 & 11 & 100 & 0.18 \\
\hline \multirow[t]{12}{*}{$2.5 \times 10^{6}$} & 7 & 1 & 10 & 1.7 \\
\hline & 21 & 1 & 10 & 0.47 \\
\hline & 42 & 1 & 10 & 0.54 \\
\hline & 7 & 2 & 38 & 0.0047 \\
\hline & 21 & 2 & 75 & 3.0 \\
\hline & 42 & 2 & 100 & 2.7 \\
\hline & 7 & 3 & 38 & 8.7 \\
\hline & 21 & 3 & 100 & 5.2 \\
\hline & 42 & 3 & 100 & 4.0 \\
\hline & 7 & 5 & 100 & 1.7 \\
\hline & 21 & 5 & 100 & 0.47 \\
\hline & 42 & 5 & 100 & 4.6 \\
\hline
\end{tabular}


were CCV positive. On Day 3, 38\% of fish exposed at $7 \mathrm{dph}$ and $100 \%$ of fish exposed at $21 \mathrm{dph}$ and $42 \mathrm{dph}$ cultured positive. On Day 5 all sampled high-dose fish were CCV positive. Sampling was terminated after Day 5 in the high-dose challenges because of excessive CCVD associated losses in the 21 and $42 \mathrm{dph}$ fish. No differences were seen in the virus loads between age groups if the fish were infected. Peak whole body virus titers ranged from $4.7 \times 10^{3}$ TCID50 $\mathrm{g}^{-1}$ (which represented the single positive fish) on Day 2 in the $7 \mathrm{dph}$ fish to $8.7 \times 10^{6}$ TCID50 $\mathrm{g}^{-1}$ on Day 3 in the $7 \mathrm{dph}$ fish (Table 1).

\section{DISCUSSION}

These data indicate a correlation between channel catfish age and CCVD susceptibility. Furthermore, we show that fish that carry vertically transmitted CCV and those that are negative have similar susceptibility to CCVD when given the virus by immersion exposure after $1 \mathrm{mo}$ of age. However, the fish from CCV positive spawns are relatively more resistant to CCVD if immersion exposed to CCV before 1 mo post hatch. We also demonstrated that maternal antibodies may contribute to the resistance in fish less than 1 mo of age. A previous study demonstrated no age-associated differences in susceptibility between 1 to 3 mo post-hatch (Plumb et al. 1975). They did not evaluate fish before 1 mo of age; which were the ages that were the most resistant to $\mathrm{CCV}$ in our study.

The presence of detectable neutralizing activity in the serum of the female brood fish and the correlation of neutralizing activity to resistance in the $8 \mathrm{dph}$ challenge suggests that maternal antibodies are partially responsible for the reduced susceptibility. Hedrick \& McDowell (1987) demonstrated that passive transfer of serum from fish with neutralizing antibodies provided protection against CCVD when challenged. In rainbow trout, maternal transfer of immunity has been demonstrated and this immunity provided protection for $25 \mathrm{~d}$ (Oshima et al. 1996). However, other factors may influence the susceptibility. Age-associated disease susceptibility has been documented in many virus-induced diseases including varicella, mumps, polio, mononucleosis and hepatitis A in humans. The mechanisms involved can include the requirement for mature, differentiated cells, the expression level of enzymes and components of the immune system, and the glycosylation state of the infected cells (reviewed in Tyler \& Fields 1996). These mechanisms could impart the observed resistance to CCV infection demonstrated in the younger fish. Additionally, heightened innate immune function in very young catfish may be occurring. Heightened innate defenses can include the presence of a more effective physical barrier. Portions of the innate defenses have been found to be enhanced in channel catfish fry including increased lysozyme production (Petrie-Hanson 1998), rapid clearance of foreign particles and increased resistance to bacterial infection (L. Petrie-Hanson unpubl. data). It is likely that similar mechanisms make the fish more resistant to initial infection by CCV. Alternatively, a lack of cells bearing virus receptors at the portal of entry may make the young channel catfish resistant to initial infection. Also, simple kinetics of exposure due to surface area and water flow may make the individual fry less likely to come into contact with the infective dose than larger, older fish. These mechanisms can influence the ability of the virus to infect the host, the ability of the virus to replicate after infection, the viral pathogenesis or the shedding and secondary transmission to other hosts. The virus loads that we observed suggest that fewer young fish are infected or infection is arrested before dissemination and secondary replication. We observed high virus loads in fish that became infected at $7 \mathrm{dph}$, suggesting that once an infection is established, the virus can replicate well. Therefore, we believe that the apparent disease resistance is more likely a function of differential infection and/or dissemination than differential pathogenesis or replicative ability.

Evidence also suggests that reduced secondary transmission may have contributed to the results that we observed. The high-dose virus replication assay demonstrated that similar numbers of fish were CCV infected at $24 \mathrm{~h}$ post-infection in all 3 age groups. Thereafter, the number of infected individuals increased most rapidly in fish exposed at $42 \mathrm{dph}$, was slower in fish exposed at $21 \mathrm{dph}$ and was the slowest in fish exposed at $7 \mathrm{dph}$. Recent research has demonstrated that channel catfish injected with low levels of CCV transmit the virus rapidly, allowing the detection of culturable virus within $48 \mathrm{~h}$ in non-injected cohorts (Thompson 2003). The different culture results that we observed are within this observed time frame for secondary transmission. Also, the stepwise kinetics of the virus loads (in both the high- and low-dose experiments) suggest that the detected increase in infected individuals was not due to the replication of the virus reaching a detection threshold on more individuals, but rather more individuals with advanced viremia were sampled. This suggests that the time span between infection and acute viremia is short, and that the progression of the detectable infections are likely due to secondary transmission, not the challenge exposure.

The immunological data is intriguing. In the challenge trials, the fish exposed to CCV before $60 \mathrm{~d}$ of age did not develop protective immunity. With the high losses, which occurred in the primary challenge of the $60 \mathrm{dph}$ fish, some of the protection seen in the second challenge 
at 120 dph may be due to innate resistance because the most susceptible fish had been culled. The fish exposed to the virus at 8,36 and $60 \mathrm{dph}$ all had significantly higher neutralizing antibodies than controls and these 3 groups were not significantly different from each other. Studies on the development of the immune system of channel catfish indicate that the organization of the secondary lymphoid tissues is poorly defined before $3 \mathrm{wk}$ of age. At this time, channel catfish are marginally capable of developing humoral and become more efficient as they age (Petrie-Hanson \& Ainsworth 1999). The trend of developing higher neutralizing titers with age are as expected for ages 23 to $60 \mathrm{dph}$, but the high titer seen in fish exposed at $8 \mathrm{dph}$ is unexpected. Because the $8 \mathrm{dph}$ fish were exposed at an age when the acquired immune system is poorly organized (an age at which channel catfish have been demonstrated to be non-responsive), it suggests that the immune system of these fish was stimulated at a later age. This suggests either recrudescence from latency, persistent infection or at least limited gene expression from latent virus. This data suggests that age will be an important consideration in establishing effective vaccination programs for CCV. Additional in-depth studies on the influence of age on anti-viral immunity is warranted.

The study suggests that an age-associated increase in susceptibility occurs and may be an important factor that influences CCVD outbreaks in fingerling production operations. Fingerling producers that have CCVD outbreaks generally report that the most common age that is affected is between 1 and 2 mo post-hatch. However, CCVD outbreaks affecting fish less than $10 \mathrm{~d}$ of age have been diagnosed in hatcheries and are associated with high losses. If the phenomenon of maternal antibody correlated age-associated resistance that we observed holds true in hatchery systems, it suggests that maternal factors may play a role in hatchery outbreaks. Noteworthy is the high level of vertical transmission we observed among the CCV positive spawns (40 to $75 \%$ sample prevalence). This opens the possibility that CCVD outbreaks in the hatchery may involve simultaneous activation of the latent virus from a large number of the population combined with a substantial portion having low maternal antibodies. This also suggests that a fundamental understanding of the biology of CCV in the aquaculture system is needed to control CCVD and to effectively apply recombinant CCV for vaccine purposes.

Acknowledgements. The authors thank S. Marinovic for performing the PCR assays and A. Irvine, R. Benton, A. Shirley and B. Edwards for assistance with the challenge trials. This research was partially funded by National Research Initiative Competitive Grant Program/USDA No. 92-37204-7925. Support was also provided by the Mississippi Agricultural and
Forestry Experiment Station (MAFES) under project \#MISV0892 and the College of Veterinary Medicine, Mississippi State University. This is MAFES publication \#J-10513.

\section{LITERATURE CITED}

Boyle J, Blackwell J (1991) Use of polymerase chain reaction to detect latent channel catfish virus. Am J Vet Res 52: 1965-1968

Fijan NN, Welborn TLJ, Naftel JP (1970) An acute viral disease of channel catfish. Technical Paper 43. US Fish and Wildlife Service, Washington, DC

Hedrick RP, McDowell T (1987) Passive transfer of sera with antivirus neutralizing activity from adult channel catfish protects juveniles from channel catfish virus. Trans Am Fish Soc 116:277-281

Hedrick RP, Groff JM, McDowell T (1987) Response of adult channel catfish to waterborne exposures of channel catfish virus. Prog Fish-Cult 49:181-187

Kancharla SR, Hanson LA (1996) Production and shedding of channel catfish virus (CCV) and thymidine kinase negative $\mathrm{CCV}$ in immersion exposed channel catfish fingerlings. Dis Aquat Org 27:25-34

Kärber G (1931) Beitrag zur kollektiven Behandlung pharmakologischer Reihenversuche. Naunyn-Schmiedebergs Archiv fuer Experimentalle Pathologie und Pharmakologie 162:480-483

Oshima S, Hata J, Segawa C, Yamashita S (1996) Mother to fry, successful transfer of immunity against infectious haematopoietic necrosis virus infection in rainbow trout. J Gen Virol 77:2441-2445

Petrie-Hanson L (1998) Ontogeny of the lymphoid organs and the immune response to Edwardsiella ictaluri in channel catfish, Ictalurus punctatus, fry and fingerlings. PhD thesis, Mississippi State University, Mississippi State, MS

Petrie-Hanson L, Ainsworth AJ (1999) Humoral immune responses of channel catfish (Ictalurus punctatus) fry and fingerlings exposed to Edwardsiella ictaluri. Fish Shellfish Immunol 9:579-589

Plumb JA (1978) Epizootiology of channel catfish virus disease. Mar Fish Rev 3:26-29

Plumb JA (1999) Health maintenance and principal microbial diseases of cultured fishes. Iowa State University Press, Ames, IA

Plumb JA, Green OL, Smitherman RO, Pardue GB (1975) Channel catfish virus experiments with different strains of channel catfish. Trans Am Fish Soc 104:140-143

Thompson D (2003) Initial studies on horizontal transmission of channel catfish virus (CCV) in selected catfish fingerling ponds in Mississippi. MS thesis, Mississippi State University, Mississippi State, MS

Tyler K, Fields B (1996) Pathogenesis of viral infections. In: Fields BN, Knipe DM, Howley PM (eds) Fields virology. Lippincott-Ravin, Philadelphia, PA, p 173-218

Wise JA, Bowser PR, Boyle JA (1985) Detection of channel catfish virus in asymptomatic adult channel catfish, Ictalurus punctatus (Rafinesque). J Fish Dis 8:485-493

Wise JA, Harrell SF, Busch RL, Boyle JA (1988) Vertical transmission of channel catfish virus. Am J Vet Res 49:1506-1509

Zhang HG, Hanson LA (1995) Deletion of thymidine kinase gene attenuates channel catfish herpesvirus while maintaining infectivity. Virology 209:658-663

Zhang HG, Hanson LA (1996) Recombinant channel catfish virus (Ictalurid herpesvirus 1) can express foreign genes and induce antibody production against the gene product. J Fish Dis 19:121-128 